\title{
Споменьт като архив. Елка Константинова в една недовършена анкета
}

Abstract: Alexandrova Nadezhda, Spomen"t kato arhiv. Elka Konstantinova v edna nedov"ršena anketa (The Memory as an Archive. Elka Konstantinova in One Unfinished Survey). "Poznańskie Studia Slawistyczne" 19. Poznań 2020. Publishing House of the Poznań Society for the Advancement of the Arts and Sciences, Adam Mickiewicz University, pp. 211-227. ISSN 2084-3011.

Elka Konstantinova is a well-known name in Poland. She has defined her work as a lecturer at the Jagiellonian University in Krakow and as a diplomat in Warsaw as an important part of her life. The text presents an unknown and unpublished survey on her memories about her work in Poland and the circumstances of preparing this unfinished survey ment to deal with the question of Konstantinova's biography and memories.

KeYwords: Elka Konstantinova; biography; memory; archive; survey

Известно е, че архивологията, без да определя спомените като сигурни документални свидетелства, не ги отрича като източници на историческа памет. В областта на хуманитарните науки понятието културна памет е със събирателно значение, което включва в себе си и формираната в дадена общност индивидуална човешка памет (Асман, 2001, 40). Спомените, които всеки човек съхранява и носи в съзнанието си цял живот, се придобиват и формират най-напред в семейната среда, в нейното обкръжение, а по-нататьк и в средата, в която попада, за да придобие знания, професия, опит, които сам да предаде нататък в родовата спирала.

Проф. д-р Елка Константинова е публична личност и типичен пример за носител на национална културна памет, която е пренесена през живота на няколко поколения в нейния род, докато добие наистина значима национална стойност. Целият ѝ живот е посветен на 
литературата, с която е закърмена и която тя самата определя като най-важното и стойностно в него. На индивидуалното си присъствие в родовата памет Елка Константинова не гледа като на привилегия, а като на съдба и голяма отговорност, като на задължение да вложи в нея своя собствен знак. И го постига. В известен смисъл, разширявайки периметьра на литературата с политическа ангажираност през $80^{- \text {те }}$ години на миналия век на страната на демократичните сили срещу тоталитарната комунистическа власт в България. В голяма степен тази нейна гражданска активност и позиция е стимулирана от видяното и преживяното в края на $70^{\text {-те }}$ и през $80^{\text {-те }}$ години в Полша. Пребиваването и работата си като преподавател по български език и литература в Ягелонския университет тя оценява като голям шанс в професионалното си развитие и начин отблизо да общува с една голяма европейска култура, отстоявала векове наред с несломима увереност и самочувствие своята идентичност и държавност.

От десетина години Елка Константинова доживява дните си в Дом за възрастни хора и е в такова състояние, което всеки човек в активна възраст пъди от съзнанието си като възможна алтернатива за дочакани старини. Преди да напусне своя дом, тя ми повери една папка, чието съдържание е повод за написването на този текст.

Става дума за последния литературен проект на Елка Константинова, наречен Анкета, върху който тя работеше по инициатива на журналиста Константин Младенов ${ }^{1}$, чието име не ми беше известно преди това. Не бих могла да кажа колко време е продължила съвместната им работа, която поради внезапната смърт на анкетиращия е останала недовършена. В началото на един от разговорите

${ }^{1}$ Докато пишех този текст, положих доста усилия да намеря данни за Константин Младенов, който е живял и работил в град Добрич, североизточна България. Опитах се да се свържа по домашен телефон, който той е написал в края на един от въпросниците си, но се оказа закрит. В интернет фигурира като автор на анкети с писателите Петьр Димитров-Рудар, Петър Славински и др. Редактор и съставител е на последното издание с творби на поета Йордан Милтенов (1919-1967), който е братовчед на Георги Константинов, бащата на Елка - талантлив автор с леви политически убеждения, с активно присъствие в литературата от 1945 г. до края на живота си. Милтенов е особено популярен приживе в литературата за деца с приказките си за Чипоноско - главен герой в негова книжна поредица (Речник, 1977, 372). В анкетата Елка си спомня с хубаво чувство за него като роднина и приятел. 
им стои датата „2 август 2008 г.“, в края на един текст с разгърнати шест въпроса от анкетиращия - „6 декември 2008 г.“. Очевидно това е годината, в която той я е посетил в дома ѝ четири или пет пъти и са провели разговори.

Папката съдържа стотина страници в машинописен препис (в два екземпляра) на проведените разговори, биографична справка и „кръг от въпроси“, подготвени от Младенов според публикуваните биографични справки за Елка Константинова (Речник, 1994, 187) и писмени отговори, които тя е подготвяла сама. В текста има множество повторения, изрезки от нейни и чужди публикации, прикачени към някои страници малки листчета с идеи да допълни отговорите си или да подсети анкетиращия за въпроси, на които би искала да отговори.

Младенов се е свързал с Елка чрез сестра ѝ Божанка Константинова $^{2}$, на която се е представил и споделил идеята си в телефонен разговор. И двете не са го познавали преди това. Божанка не е успяла да се запознае с него лично. Върху едно листче (без дата) в папката Елка е отбелязала, че той е починал след инсулт. Не успях да разбера как е стигнала до нея тази вест въпреки усилията ми, за които споменах.

Текстьт на тази недовършена Анкета не бих определила като новооткрит исторически извор (Богданов, 2014, 137), тъй като представя известни в културната ни история факти и само припомня познати публикации, активности и общувания на Елка Константинова като литературен критик, преподавател и популярна обществена фигура. Доверието, с което тя ми предостави тази папка, ме задължава да отбележа факта, да уважа нейното последно усилие за литературен труд, както и паметта на човека, пристьпил с уважение към нейните спомени и към приноса ѝ в българската култура. Съхранявам папката, но тя не ми принадлежи, не мога да реша сама съдбата ѝ. Ще я реши най-близкият ѝ човек в момента, сестра ѝ Божанка Константинова, която с основание оспорва част от твърденията на Елка в анкетата, появили се и в някои публикации за нея в жълтата преса. Текстът, който съм подбрала, се публикува тук с нейното одобрение и съгласие.

${ }^{2}$ Божанка Константинова (1941), също литератор, доцент, специалист по детска литература, преподавател в СУ. 
Елка няма личен архив, или по-точно доколкото има запазени документи, свързани с нейната литературна дейност, се съхраняват от сестра ѝ в семейния им архив Константинови. С голяма лекота тя се разделяше с материалните неща, щедро подаряваше ценни книги от личната си библиотека, не събираше дори своите книги и публикации. Не следваше в това отношение примера на баща си литературния критик Георги Константинов (1902-1970), оставил след себе си богат архив, който включва и част от архива на Николай Лилиев ${ }^{3}$.

Подбраните и публикувани тук фрагменти от Анкетата следват „кръга от въпросите“ на анкетиращия, който според традицията в жанра проследява хронологията на важните събития в живота на Константинова - ранно детство и семейна среда, образование, професия и реализация, колеги и приятели, принос в културата, книги, обществено признание. За разлика обаче от така подредените въпроси отговорите на анкетираната съдържат множество повторения, връщания към вече разказани събития и случки, към изразени отношения и мнения в областта на литературата и политиката като например темите за присъствието на Лилиев в живота ѝ, за постмодернизма и българската проза на автори, дебютирали през 90-те години на миналия век и др.

Макар и пораснала в ръцете на един от най-талантливите български поети, Николай Лилиев (1885-1960), Елка Константинова като критик следеше внимателно авторските изяви предимно в белетристиката. Интересуваше се от новите теми и идеи, от разказваческото майсторство, от връзките на въображението с реалността в наративните жанрове, от концепциите и формулировките на новопоявилата се в българската литература и изкуство в края на $80^{- \text {те }}$ и през $90^{- \text {те }}$ години естетика на постмодернизма. Преди това, дори в окованата от догмите художествена действителност, без да пренебрегва изискванията на задължителния соцреализъм в изкуствата, и особено в актуалната

${ }^{3}$ През 1978 г. голяма част от библиотеката и архива на Георги Константинов постъпи във фонда на Националния литературен музей (НЛМ), където има архивен фонд на негово име и на името на поета. Малко по-късно последната част от архива на Лилиев, намираща се в къщата на сестра му в Лозенец, също беше предоставена за съхранение в НЛМ. 
критика, в която тя усещаше силата си, в конкретните си анализи успяваше да изрази собствената си естетическа и етична оценка, да разпознае безпогрешно художественото явление като литературно събитие.

Променената политическа ситуация в страната от края на $80^{\text {-те }}$ и през 90-те години тя прие безусловно като естествено състояние на духа, родил и новите таланти в литературата ни, които открои още при първите им изяви в своите критически текстове. Нейните фаворити от това време - Алек Попов, Здравка Евтимова, Емилия Дворянова, Албена Стамболова, Елин Рахнев, Георги Тенев вече се радват на широк кръг читатели и вън от пределите на страната. Някои от тях са преведени на полски от нейни колеги и някогашни студенти - Войчек Галонзка, Целина Юда, Малгожата Внук, Кристина Мигдалска, Галя Симеонова - Конах ${ }^{4}$ и др. Не е случаен фактът, че пребиваването на Елка Константинова в Полша съвпада със засилен интерес към българската литература.

С любов и умиление в първите страници Елка си спомня за детството и младостта, за къщата в Лозенец (някогашния Курубаглар), в която е расла под топлите грижи на баба си Божанка, дядо си Минчо Чакъров (когото, като проговорила, нарекла „тати деди“, а след нея и другите негови внуци възприели това обръщение) и на своя вуйчо, поета Николай Лилиев. Забележителна семейна среда, която от най-ранна възраст култивира в нея любов и вкус към изкуството, потребност да бъде в него и встрани от него, подготвя сетивата и уменията ѝ да се вживява и да го оценява, програмира отрано и професионалния ѝ избор. Една нейна пощенска картичка, изпратена от Костенец на 4.8.1947 г. до Лилиев, говори много не само за чувствата ѝ, но и за вече формираните и осъзнати като необходимост знания и потребност да ги практикува и усъвършенства. Говори и за

${ }^{4}$ Г. С. Конах, близка приятелка на Е. Константинова от времето на пребиваването ѝ в Краков. Тогава литературоведката започва книгата си за Н. Лилиев - Поетът и лилията (1999), а през 2007 г. съставя антология на българската проза, в която и превежда част от разказите на полски език - Човекът с много имена (Człowiek o wielu imionach ) (2007). В антологията са включени разкази от Емил Андреев, Сава Василев, Валентин Георгиев, Георги Господинов (неговата творба дава заглавието на книгата), Емилия Дворянова, Здравка Евтимова, Деян Енев, Райна Маркова и Алек Попов. 
желанието ѝ да демонстрира различното си отношение и избор към хората от семейството с факта например, че пропуска да поздрави баба си, която е проявявала строгост към нея, което споделя и в $A \mu_{-}$ кетата:

Мили Вуйчо, пиша ви от един от най-хубавите кътове на България. Разположихме се в недовършената ни още виличка, но се чувстваме много добре, защото сме сами и сме у дома. Затова, вуйчо Николай, много хубаво ще бъде, ако се съгласите да дойдете с татко. Чакаме ви с голямо нетърпение. Ако дойдете, ще се чувствам безкрайно щастлива, защото без вас ще забравя съвсем френски. Ако е възможно елате с тати деди, ще говорим тримата френски, аз ще правя диктовки, ще ходим на разходки и ще бъде много хубаво. Целунете от мене тати деди и свако. Целува ви Елито. (Семеен архив, Б. Константинова. Датата е според пощ. клеймо върху плика. Картичката е илюстрована с изглед от водопада в Костенец).

\section{Ето фрагменти от разказа ѝ за детските години в къщата в Лозе- нец ${ }^{5}$ :}

Никога не съм допускала, че толкова много ще живея - на 78 години съм сега. Преживях тежки операции. Мислех, че ще умра рано. На моите сегашни години и вуйчо Николай, и баща ми не бяха вече живи [...].

Най-щастливите ми спомени са свързани с детството ми [...] беше изключително щастливо. Родих се в къщата на Николай Лилиев, на нашия вуйчо Николай, както го наричахме ние всички внуци от трите деца на баба ми Божанка. Това всъщност беше къщата на дядо ми по майка - Минчо Чакъров - в квартал Лозенец, на ул. „Мерхамль“ $11^{6}$.

Спомням си двора с кладенеца и големите дървета - двете високи тополи, овощните дървета - праскови, кайсии, череши, круши [...] зеленчуковата градина с всички зеленчуци - домати, чушки, краставици, патладжани... Цял чифлик беше нашият двор, а вуйчо Николай беше заклет вегетарианец. И аз не обичам месо. Като дете обикнах вкусните вегетариански гозби. Не разбрах защо вуйчо Николай беше вегетарианец. Като го питах, все отговаряше: Много месо съм изял, много цигари съм изпушил $[\ldots]$. Вече нито ще пуша, нито месо ще ям [...]. Беше здрав човек [...]. Умря от лекарска грешка.

Дядо ми Минчо Чакъров е завършил френска филология във Франция, в град Гренобъл. Бил е от богато семейство в Търново Сеймен, Южна България, завършил е образованието си на родителска издръжка. Работил е като учител и училищен инспектор. Баба ми Божанка е била негова ученичка. Той беше 8-9 години

\footnotetext{
${ }_{5}^{5}$ Фрагментите, които публикувам тук, са подбрани от мен със съкращения, отбелязани с многоточия - бел. Н.А.

${ }^{6}$ Сега е ул. „Николай Лилиев“. Къщата беше разрушена след 1990 и на мястото ѝ е построена жилищна кооперация.
} 
по-възрастен от нея. Много рано тя и вуйчо Николай останали кръгли сираци и дядо Минчо е поел грижата за нея и братчето ѝ няколко години преди тя да му стане жена. Беше изключително благороден и работлив човек, той е издържал и образовал двамата сираци. Баба ми Божанка е станала също учителка, а вуйчо Николай получил високо образование в Швейцария, а после в Париж. Преди това той е завършил и престижната Свищовска търговска гимназия [...].

Дядо Минчо много ме глезеше, вуйчо Николай си мълчеше, а най-строга беше баба $[\ldots]$.

За мен Николай Лилиев беше най-близък човек, той ме е отгледал. Най-ранните ми спомени са свързани с него. По това време татко е бил командирован в Белград и двамата с мама са живели там няколко години.

Запомнила съм как, като те се завърнаха вкъщи, вуйчо Николай ме държеше за ръка, а в двора влезнаха двама непознати за мен мъж и жена. Жената много елегантна, мъжът до нея - също. Бяха непознати, напълно забравени от мен хора [...].

В къщата ни в Лозенец живеехме всички заедно. На втория етаж беше кабинетът на вуйчо Николай, неговата стая с много, много книги [...].

Николай Лилиев беше драматург на Народния театър. Беше отдаден на театъpa. Но намираше начин да ми отделя от времето и вниманието си. [...]. Той винаги ми беше опора и по-късно, и в Университета, и в Литературния институт... Като академик редактираше издания на Института, различни сборници [...]. Вуйчо Николай винаги ми внушаваше, че има много благородни и добри хора около нас.

Избирайки литературната критика за своя професия, Елка продължава делото на баща си - Георги Константинов, който, заедно с Николай Лилиев, е човекът, чиито уроци и пример за трудолюбие и почтеност тя следва през всичките години в живота и творческата си дейност. Георги Константинов (1902-1970) е литературен историк и критик, чието обемно и значимо творческо дело е белязано от идеологическата стигма върху българската литература, наложена по времето както на пролетарската диктатура от края на $40^{-т е}$ и началото на $50^{-т е}$ години на миналия век, така и в периода на настьпилото размразяване след 1956 г., когато комунистическата власт в България прави разумна преоценка на политиката си по отношение на културното наследство без да отменя изискванията на вече възприетия и смятан за достатъчно утвърден през годините метод „социалистически реализъм“ (Александрова, 2020, 262). Арестуването му непосредствено след 9.9.1944 г, затварянето и обвинението в шовинизъм заради книгата му Душата на Македония (1941) е преживяване, което оставя трайна следа в живота и професионалния му път (Александрова, 2019, 249). 
Бащата на Елка и Божанка Константинови е не само талантлив литератор и утвърдено име в литературата, но и добър човек с много приятели, поощрил началните стьпки на много автори от своето и от следващите поколения, на които се оказва съвременник. Естествено е писателят да се радва и поощрява професионалния избор на двете си дъщери, които доказват през годините, че натрупаното в семейната среда знание и отношение към литературата и изкуството е солидна основа, върху която си струва да се гради и личен принос в българската култура. И двете успяват да постигнат през годините това като автори, като преподаватели, като редактори на множество ценни издания.

Литературната среда, в която Елка Константинова попада след завършването на университета, за нея се оказва естествено продължение на семейната като стимул за професионалното ѝ развитие. Първият, когото тя помни с голяма благодарност и скръб по тъжния му край, е самоубилият се на 31.12.1966 г. талантлив и високо ерудиран литератор Минко Николов (1929-1966) (Речник, 1994, 252):

Минко Николов беше чист литератор. Не знам защо посегна на живота си. Може би по лични причини, не по политически. Много млад си отиде. Той е от Троян. Като ходих там, ми казаха, че целият му род са меланхолици и лесно се отчайват от житейските несправедливости. Благодарение на Минко аз защитих дисертация за Георги Райчев ${ }^{7}$. Докато в Института казваха - този автор няма да стане, буржоазен е, и с тоя диаболизъм... Подкрепи ме тогава и Георги Караславов ${ }^{8}-$ Как Гюро буржоазен! Той е дълбоко социален!

Не можех да стана аспирантка в Университета без подкрепата на Минко Николов, без него нямаше да мога да постигна много от това, което съм успяла да постигна. Благодарение на неговата препоръка станах преподавател по литература в Библиотечния институт.

И Георги Райчев, и Георги Караславов бяха приятели на баща ми. Помня Георги Райчев като бодър, весел и засмян човек. Беше близък приятел и на вуйчо Николай, и на татко. Книгата ми за Георги Райчев излезе по-късно, през 1982 в издателство „Български писател“.

Мнозина от колегите и приятели на Елка вече са Отвъд. В момента тя разговаря със самотата. Винаги обградена с хора, винаги в помощ и подкрепа на някого, сега тя трябва да я открие и преживее като

${ }^{7}$ Г. Райчев (1882-1947) (Константинова, 1982).

${ }^{8}$ Г. Караславов (1904-1980) (Константинова, Константинов, 1971). 
непознато човешко състояние. Не си представяше това, което ѝ се случи и не мислеше за него. Беше заредена с оптимизъм. Съдбата, която е била щедра към нея, сега ѝ отне дори онова, което тя оценяваше като неотменно притежание - работата, литературата, общуването, културния живот:

В Института за литература, където премина целият ми дълъг половинвековен трудов стаж до пенсионирането ми, най-близки мои приятели бяха проф. дфн. Тончо Жечев ${ }^{9}$, проф. дфн. Кръстю Куюмджиев ${ }^{10}$ и проф. кфн. Здравко Петров ${ }^{11}$. Работехме заедно върху историята на новата българска литература (от Освобождението до съвременността ${ }^{12}$ ) и върху Речника на българската литература (от Паисий до наши дни ${ }^{13}$ ). Щастлива се чувствах, че полагам много труд и амбиция в изготвянето и на пълна анотирана библиография на българската литература, на всичко писано на български език за нашата и за чуждите литератури в книгите, сборниците и периодиката.

С тримата ми приятели Тончо, Здравко и Кръстю се срещахме почти всеки ден или в Института, или по обяд в кръчмата „Видинска среща“ на ул. „Раковски“"14 и разговаряхме върху общата ни институтска работа, върху текущия литературен и културен живот. Най-много подробности за живота в СБП знаеше Здравко Петров, който най-дълго прекарваше времето си в писателското кафене на ул. „Ангел Кънчев“"15, където се помещаваше и СБП. Здравко нямаше семейство, живееше сам и беше пълен господар на времето си, затова имаше тази възможност. Винаги беше готов да ни даде пълна информация за всекидневието на литературния живот. Аз пък бях най-информирана за театралния живот. Като племенница на Николай Лилиев, дългогодишен драматург на Народния театър, тази информираност и ходенето на театър беше необходимост, семейна традиция.

Как се отнасяха с вас колегите Ви в Института?

Само двама от тях се отнасяха към мене като дъщеря на фашист - Васил Колевски ${ }^{16}$ и Илия Конев ${ }^{17}$. Но усилията и резултатите от работата ми обезсилваше

${ }^{9}$ Тончо Жечев (1929-2000).

${ }^{10}$ Кръстю Куюмджиев (1933-1988).

11 Здравко Петров (1928-2000).

${ }^{12}$ Има предвид Очерчии по история на българската литература след девети септември 1944 година. В две книги (1979). Първа книга - теория, роман, драма (1979); автори В. Колевски, Т. Жечев, В. Бояджиева. Втора книга (1980) - поезия, повест и разказ; автори Здр. Петров, Е. Константинова, Кр. Куюмджиев.

${ }^{13}$ Речник (1976-1977-1982).

${ }^{14}$ Сега ресторант с немска кухня "Warsteiner".

${ }^{15}$ След 1992 и влизането в сила на Закона за реституцията кафенето и администрацията на СБП освободиха сградата на ул. „Ангел Кънчев“ 5.

${ }^{16}$ В. Колевски (1925-2018).

${ }^{17}$ Ил. Конев (1928-2009). 
това тяхно отношение. Вложих много труд в създаването на библиографията в Института и паралелно с многото си чисто технически задължения успях да защитя и дисертационния си труд, активно сътрудничех в литературния печат. Във в. „Народна култура“ главният редактор Христо Сантов ${ }^{18}$ ми възлагаше редакторски задачи срещу добър хонорар. Писателят Камен Калчев ${ }^{19}$ също оценяваше литературните ми умения и като главен редактор на сп. „Септември“, а по-късно и като директор на издателство „Български писател“ ме е назначавал там на щатна работа. Той ме предложи и за член на СБП и бях приета в Съюза и с подкрепата на Георги Караславов.

Спомняте ли си коя беше първата Ви публикация?

Да, във в. „Литературен фронт“. Беше ми възложена от Георги Джагаров ${ }^{20}$ актуалната тема - Постиженията на съвременния български разказ. Татко много се зарадва на тази моя научна студия и заживя с надеждата, че ще се посветя успешно на литературна дейност.

Вие сте автор на петнайсет книги. Коя от тях иеенте най-много днес?

И днес сигурно бих написала тези книги, но бих вложила повече разсъждения върху актуалните идеи на днешната епоха. Бих се съсредоточила върху авторите, които особено харесвам. Например Теодора Димова. Романът ѝ Майките с незабравимия символичен образ на учителката Явора, която припомня на съвременния читател за делата на Спасителя. Днес харесвам и пиша за онези романисти и разказвачи, които повече разсъждават върху живота и характерите на своите персонажи, отколкото да описват случки и събития. Вълнуват ме движенията на душите, на мислите, духовните приключения на съвременния човек. Освен Теодора Димова харесвам и съвременната философска проза на Емилия Дворянова нейните героини ката Алиса, Госпожа Г., La Valetta... Харесвам този тип героини, които символизират силата на човешката любов, преобразяваща реалността чрез тайнството на съзнанието и на душите си. Харесвам и чета също Здравка Евтимова и Албена Стамболова, чиито героини излъчват силна духовна енергия около себе си. Харесвам техните мистично раздвоени персонажи, които след тежки и разтърсващи ги страдания преодоляват илюзиите си за пълнотата на човешкото щастие. Силно вълнуващ у тях е страхът от живот без илюзии и търсенето на сили да преодолеят този страх, начините, с които постигат това състояние на разбиране и смирение пред трудностите в живота...

Ние, земните хора, живеем с илюзията на единствените мислещи и разумни същества в космоса. Но нима не е възможно в безкрайния космос да съществуват и други? Аз възприемам безкрайността, самата вселена като Бог, за което говорят и много от съвременните учени, изследователи на Космоса.

Попаднала през 1978 г. в Краков, в един от най-старите университети на Европа, Ягелонския, Елка Константинова преподава. Прави го

\footnotetext{
${ }^{18}$ Хр. Сантов (1926-997).

${ }^{19}$ К. Калчев (1914-1988).

${ }^{20}$ Георги Джагаров (1925-1995).
} 
вещо и с лекота. Обича да споделя знанията си и студентите я обикват. Много от тях се превръщат в нейни близки приятели, които ѝ гостуват в София, поддържа с тях постоянна кореспонденция. Тя успява да скъси дистанцията, да бъде част от тяхната общност с решението си веднага самата тя да продължи да учи.

И не само мястото, но и времето, в което пребивава в Краков, оказва решаващо влияние върху нейното мислене, себепознание и социална активност. Това е вдъхновяващото време на „Солидарност“, на Лех Вален$\mathrm{ca}$, на заразителния пример на поляците за всички народи от „съветския блок“ в борбата им за демокрация и независимост. Контактите, които създава със своите полски колеги, тя оценява като едно от най-ценните духовни придобивки в живота си. Многобройните ѝ приятелства в Полша от тези години са живи и днес в спомените и мислите ѝ. Могат да се оценят и като културен факт, прехвърлил нейния личностен периметьр ${ }^{21}$. Защото в Полша тя успя не просто да обучи студенти на нашия език, но и да им предаде любовта си към него, към българската култура и литература, изпълнена със съзнанието, че продължава благородната мисия на своите бележити предшественици Боян Пенев (1982-1927), Дора Габе (1886-1983), Петър Динеков (1910-1992), Блага Димитрова (1922-2003).

В Краков българистиката е най-стара. Боян Пенев е работил дълги години там. Създадена е в нелегалност от проф. Розвадовски ${ }^{22}$.

${ }^{21}$ Повечето от споменатите в нейния разказ съвременни български автори са преведени на полски.

22 Ян Розвадовски (7.12.1867-14.03.1935) - видният полски езиковед индоевропеист, който през учебната 1898/1899 г. за първи път в историята на Ягелонския университет чете лекции „Граматика на живия български език и неговия диалектен и исторически развой“ 3 часа седмично, а в провеждания в университета Славистичен семинар води „Четене и обяснение на текстове на новобългарски език“ 2 часа седмично. Същата учебна година на заседание на Полската академия на знанията в Краков Розвадовски произнася и лекция „Из изследванията върху българската фонетика“. След поемане на Катедрата по индоевропеистика на Ягелонския университет Розвадовски престава да се занимава с българистика и славистика, но той остава първият краковски учен, заинтересувал се от въпросите на българския език и въвел неговото преподаване, а годината 1898 се смята официално за начало на българистиката в Ягелонския университет (Benczew, Patelski, 2007, 116-124). 
Когато бях там, катедрата се ръководеше от акад. Славски ${ }^{23}$, езиковед, член на четири академии. Беше автор и на книга за българската литература. Не знаех полски преди отиването ми в Краков. Говорех френски и руски, но бързо разбрах, че те не обичат руския език [...]. Колегите ми много ме обикнаха заради бързината, с която научих полски. Всеки ден по 6 часа ходех на курс за чужденци [...]. Разбира се изучих подробно и полската литература, дълго стоях в Полша два мандата. Имам много полски приятели колеги и мои студенти.

И днес поддържам близки връзки с приятелите и колегите ми от Полша, с Полския културен център в София...

В Полша си написах докторската дисертация и благодарение на това, че там превеждат много повече световна литература. Там прочетох почти цялата световна фантастика [...]. Тя беше за научната фантастика. Със съвети ми помагаше Любен Дилов ${ }^{24}$. Но написах по-голямата ù част докато бях в Полша, където пет години преподавах български език и литература в Ягелоския университет в Краков. Там изчетох много полски и чужди фантасти...

На защитата ме подкрепиха Тончо Жечев, Кр. Куюмджиев, Здравко Петров и др. Но имах и много противници. Минах с два гласа $[\ldots]$.

В Полша освен полски усъвършенствах и френския си език, с четене и курсове. Като бях министър на културата, за пръв път посетих Франция и моят френски беше изненада за техния министър на културата, когато разбра, че никога преди това не съм била там [...].

Имам желание да разказвам за широко скроени хора. Всичко в моя живот е ставало благодарение на приятелства с изключителни хора. Покрай Лилиев познавах Владимир Василев [...]. И тримата мои най-близки приятели - Здравко Петров, Тончо Жечев и Кръстьо Куюмджиев бяха изключителни личности. Макар и активно практикуващи идеологията, не бяха тесногръди като други. Те ме приеха в своя кръг, което за мен беше щастие. До нас най-близък приятел и колега

${ }^{23}$ Франчишек Славски (13.05.1916-19.01.2001) - изтъкнатият полски езиковед, славист и българист, диалектолог, етимолог, автор на Граматика на българския език, Българо-полски речник, Южнославянска диалектология с избрани диалектни текстове. България, Етимологичен речник на полския език (5 тома, 1952-1982), Праславянски речник и много статии в областта на българското езикознание и старобългарската книжнина. Първият полски езиковед в Ягелонския университет, защитил докторат изцяло на българистична тематика (1943). Води първите занятия по български език в новооткритата специалност българистика в Катедрата за славянски филологии на Ягелонския университет през учебната 1950/1951 г. През 1949-1968 г. е рьководител на Отдела за южнославянски филологии в Катедрата по славянски филологии, 1969-1973 г. е ръководител на Катедрата, а 1974-1986 г. е Директор на Института за славянски филологии при Ягелонския университет. Член на четири Академии на науките - Полската академия на науките, Полската академия на знанията, Австрийската академия на науките и Българската академия на науките, doctor honoris causa на Софийския университет „Св. Климент Охридски“ и на Лодзкия университет. Благодаря на проф. Катя Михайлова, която направи справката за двамата полски учени.

${ }^{24}$ Любен Дилов (1927-2008). 
беше Цветан Стоянов. Изключителен познавач на световната и българската литература. Беше гениален, ние го боготворяхме. Той пишеше за всички европейски и американски литератури.

Когато се запознахме, като чу, че съм племенница на Лилиев, започна да рецитира негови стихове. Попитах го: Ама целия ли го знаете? - Разбира се, - отговори той.

В края на 80-те години с отговорността на утвърден в професията си интелектуалец, обществено ангажиран човек и демократ, Елка Константинова се включи активно в политиката на страната на демократичната опозиция у нас. Беше сред основателите на Комитета за гласност и демокрация, на Съюза на демократичните сили (СДС), възстанови и оглави новата Радикал демократическа партия (РДП) като част от този съюз, стана депутат във Великото народно събрание (BНC), министьр на културата в първото демократично правителство след 1989 година и пълномощен министьр на България в Полша във второто правителство на СДС.

Елка Константинова преживя тежко разпадането на СДС, а преди това и разцеплението на РДП, здравословното ѝ състояние се влоши и след заврьщането си от Полша през 1998 г. тя се оттегли от политиката, за да се върне към литературните си занимания. Всъщност и тях, като най-съществена част от себе си, тя беше подчинила и включила в осъществяването на идеята си за една политика, следваща достойните традиции на основателите на РДП в България от началото на миналия век - писателя Тодор Г. Влайков и приятеля му Найчо Цанов. И последва Влайковия пример на обратния ,завой““25 към истинското си призвание. Тя вероятно имаше много основания да бъде удовлетворена от свършеното в първите дни, месеци и години на участието си в процеса за демократизация на страната. Но имаше основания и за обратното - да бъде огорчена и обидена, което не си позволи. Просто се върна към предишния си живот и го продължи с литературата, с писането и преподавателската си дейност, с любов към своите ученици, студенти, докторанти, съмишленици и приятели:

\footnotetext{
${ }^{25}$ Под заглавие Завои (1935) писателят описва в книга пътя си на писател, политик и общественик и обяснява решението си да сложи край на политическата си кариера с желанието си да посвети на литературата останалата част от живота си.
} 
Вече съм на 78 години и никак не ми се говори и не ми се мисли за политика и особено за моята собствена политическа дейност. Не се отказвам от нищо, което извърших като политик, бях министьр на културата в първото демократично правителство на СДС, с министър-председател Филип Димитров ${ }^{26}$, формирано по времето на първия демократично избран президент на България, д-р Желю Желев ${ }^{27}$ - един от най-благородните и демократично мислещи хора, когото имах късмета да познавам и с когото да работя след настъпилата промяна на 10 ноември 1989 година. Гордея се, че съм един от възстановителите в края на 1989 година на Радикалдемократическата партия, която беше партията на моя баща, близък приятел на писателя Тодор Влайков ${ }^{28}$, който заедно с Найчо Цанов е нейният пръв създател и дългогодишен лидер, запомнен в историята на българския политически живот като един от най-честните и почтени негови организатори и участници.

В днешно време тази партия не можа да просъществува дълго ${ }^{29}[\ldots]$. Никое догматично учение вече не може насила да наложи постулатите си, свободни сме сами да търсим истината и да живеем с нея, освободени от илюзии. Останахме зависими само от самите себе си и от начина, по който оценяваме стремежа си към недостижимото познаване на реалността, към осъществяване на личните си амбиции. Християнската религия и високото изкуство сега ни помагат да направим свободно своя екзистенциален избор в полза на близките си, на приятелите си, на народа си, на достойните хора, на децата, на младите. Помагат ни да живеем честно и да сме полезни на другите [...]. Днес всичко зависи от нас, от пътя, който избираме: достойния или недостойния... Литературата на българския постмодернизъм сравнително бързо се ориентира в манталитета на променящия се съвременник, който не само осъзнава цената на човешката свобода, но и умее да се възползва от нея, всеки по свой начин в зависимост от нравствените си устои и принципи.

Докато беше във форма, макар умората да си беше казала вече думата и здравето да ѝ даваше сигнали, че трябва да намали темпото, тя продължи да се труди активно. Не можеше да не участва в културния живот, да не чете лекции, да не публикува. След оттеглянето си от политическия живот написа книгата Какво щзе кажем ние на младите сърия (2002), която бих определила като заветна и като продължение на предхождащата я - Лечебната сила на литературата (1992), от времето на активната й работа като министьр на културата.

${ }^{26} 8.11 .1991-30.12 .1992$. г. В момента е конституционен съдия и зам. председател на Венецианската комисия към Съвета на Европа.

27 Дисидент, автор на книгата Фашизмът (1982), председател на СДС, президент на България (1990-1997).

${ }^{28}$ Тодор Г. Влайков (1865-1943), основател и главен редактор на сп. „Демократически преглед“. Найчо Цанов (1857-1923).

${ }^{29}$ Възстановената през 1989 г. РДП с председател Захари Петров сега е част от СДС. 
Заглавието на последната ѝ книга е стих от знаковата творба на Николай Лилиев - Като утеха сетна проблясват небесата, изразяваща мислите и духовните прозрения на поета след края на Пьрвата световна война и националната покруса от нейните последствия за страната и хората в нея. Не е случаен изборът на това заглавие, подчертаващо връзката на Елка Константинова със словото на поета, което в българската поезия е слово от Бога. Освен заветна, тази книга е и равносметка, и нова за нея тематична територия, свързана с анализ на присъствието и особеностите в интерпретирането на християнската проблематика в новата и съвременна българска литература, с преосмислянето на християнския светоглед и неговите морални категории и ценности. Освен цялата първа част, в която темата е поставена като проблеми и въпроси, очакващи отговор от литературата и изкуството, но и от обществото като цяло, тя е основен лайтмотив и в текстовете, посветени конкретно както на христоматийни автори като Иван Вазов, Пейо Яворов, Димчо Дебелянов, така и на младите, дебютирали през 90-те години Алек Попов, Георги Господинов и др.

В днешно време няма защо Елка Константинова да използва жанра на фантастиката, за да стигне до проблема за вярата в Бога и за човешкия разум с неговата отговорност за съдбата на света. В тези книги тя разсъждава не като вещ теолог, а като литератор за християнската образност в българската литература като резултат на специфичното българско отношение към Бога и религията, отразено в творбите на българските писатели. Разглежда го в контекста на познанията си върху темата в руската и полската литература, върху класиката и съвременността. За своята вяра и упование в Бога Елка Константинова вече говори направо и директно, както и в цитираните тук фрагменти от недовършената ѝ анкета.

На въпрос на Константин Младенов дали анкетата не би провокирала у нея желание да напише своите мемоари, тя отговаря отрицателно. Отговаря, че анкетата е достатъчен начин да сподели спомените си и беше поласкана и зарадвана от идеята на този литератор, който изчезна така, както се беше появил в живота ѝ. 


\section{Литература}

Александрова, Н. (2019). Димитър Талев, Георги Константинов и методът. В: Димитър Талев - кодът на историята и лабиринтите на настоящето в литературата. Ред. А. Антонова, Е. Трайкова, М. Иванова-Гиргинова. София: Изд. центьр „Боян Пенев“, с. 249-261.

Александрова, Н. (2020). Васил Пундев, Георги Константинов, историята и cn. „,Златорог“. В: Българската литературна критика - позиции и контексти. Ред. П. Ватова. София: Изд. центьр „Боян Пенев“, с. 262-274.

Александрова, Н., Константинова, Е. (1983). Новооткрити писма на Димчо Дебелянов до Николай Лилиев. „Литературна мисъл“ № 5, с. 139-143.

Александрова, Н., Константинова, Е. (1984). Николай Лилиев и неговият архив. Алманах „Море“, с. 305-315.

Александрова, Н., Константинова, Е. (1985a). Поетът и неговият изследовател. Алманах „Море“, с. 268-274 (за Н. Лилиев и Г. Константинов).

Александрова, Н., Константинова, Е. (1985b). Писма на Николай Лилиев до роднините му. „Простори“ № 2, с. 87-93.

Александрова, Н., Константинова, Е. (1986а). Димчо Дебелянов в оценките на съвременниците си. „Литературна мисъл“" № 9, с. 111-116.

Александрова, Н., Константинова, Е. (1986b). Писма на Дора Габе до Николай Лилиев. „Хоризонт“ № 3-4, с. 128-133.

Асман, Я. (2001). Културната памет. Прев. А. Димова. София: Изд. Планета-3. Богданов, И. (2014). Архивология. София: Изд. Нов български университет.

Константинова, Е., Константинов, Г. (1971). Книга за Георги Караславов, Критически оченки, спомени, размисли. София: Български писател.

Константинова, Е. (1982). Георги Райчев. София: Български писател.

Константинова, Е. (1985). Силуети от вчера и днес. София: Български писател.

Константинова, Е. (1986). Георги Караславов. София: Отечество.

Константинова, Е. (1987а). Българският разказ от вчера и днес. София: Български писател.

Константинова, Е. (1987b). Въображаемото и реалното. Фантастиката в българската художествена проза. София: Университетско издателство „Климент Охридски“.

Константинова, Е. (1992). Лечебната сила на литературата. София: ИК „Въпреки“. Константинова, Е. (2002). Какво ще кажем ние на младите съриа. София: ИК „Въпреки“.

Речник (1976-1977-1982). Речник на българската литература. В три тома. София: Изд. БАН.

Речник (1994). Речник по нова българска литература 1878-1992. София: Изд. Хемус.

[Aleksandrova, N. (2019). Dimit"r Talev, Georgi Konstantinov i metod"t. V: Dimit"r Talev - kod"t na istoriâta i labirintite na nastô̂ŝeto v literaturata. Red. A. Antonova, E. Trajkova, M. Ivanova-Girginova. Sofiâ: Izd. cent”r „Boân Penev“, s. 249-261. 
Aleksandrova, N. (2020). Vasil Pundev, Georgi Konstantinov, istoriâta i sp. ,,Zlatorog “. V: B"lgarskata literaturna kritika - pozicii i konteksti. Red. P. Vatova. Sofiâ: Izd. cent"r „Boân Penev“, s. 262-274.

Aleksandrova, N., Konstantinova, E. (1983). Novootkriti pisma na Dimčo Debelânov do Nikolaj Liliev. „Literaturna mis"1“ № 5, s. 139-143.

Aleksandrova, N., Konstantinova, E. (1984). Nikolaj Liliev i negoviât arhiv. Almanah „More“, s. 305-315.

Aleksandrova, N., Konstantinova, E. (1985a). Poet"t i negoviât izsledovatel. Almanah „More“, s. 268-274 (za N. Liliev i G. Konstantinov).

Aleksandrova, N., Konstantinova, E. (1985b). Pisma na Nikolaj Liliev do rodninite mu. „Prostori““ № 2, s. 87-93.

Aleksandrova, N., Konstantinova, E. (1986a). Dimčo Debelânov v ocenkite na $s$ "vremennicite si. „Literaturna mis"1“" № 9, s. 111-116.

Aleksandrova, N., Konstantinova, E. (1986b). Pisma na Dora Gabe do Nikolaj Liliev. „Horizont“", № 3-4, s. 128-133.

Asman, Â. (2001). Kulturnata pamet. Prev. A. Dimova. Sofiâ: Izd. Planeta-3.

Bogdanov, I. (2014). Arhivologiâ. Sofiâ: Izd. Nov b"lgarski universitet.

Konstantinova, E., Konstantinov, G. (1971). Kniga za Georgi Karaslavov, Kritičeski ocenki, spomeni, razmisli. Sofiâ: B"lgarski pisatel.

Konstantinova, E. (1982). Georgi Rajčev. Sofiâ: B"lgarski pisatel.

Konstantinova, E. (1985). Silueti ot včera i dnes. Sofiâ: B"lgarski pisatel.

Konstantinova, E. (1986). Georgi Karaslavov. Sofiâ: Otečestvo.

Konstantinova, E. (1987a). B"lgarskiât razkaz ot včera i dnes. Sofiâ: B"lgarski pisatel.

Konstantinova, E. (1987b). V"obražaemoto $i$ realnoto. Fantastikata v b"lgarskata hudožestvena proza. Sofiâ: Universitetsko izdatelstvo „Kliment Ohridski“.

Konstantinova, E. (1992). Lečebnata sila na literaturata. Sofiâ: IK ,V"preki“.

Konstantinova, E. (2002). Kakvo ŝe kažem nie na mladite s"rca. Sofiâ: IK „V”preki“.

Rečnik (1976-1977-1982). Rečnik na b"lgarskata literatura. V tri toma. Sofiâ: Izd. BAN.

Rečnik (1994). Rečnik po nova b"lgarska literatura 1878-1992. Sofiâ: Izd. Hemus].

Benczew, J. M., Patelski, M. (2007). Jana Michała Rozwadowskiego zainteresowania Słowiańszczyzną. B: Slovanský svět očima badatelì a publicistů 19. a 20. století. Praha: Etnologický ústav AV ČR, c. 116-124. 